\title{
Brucella canis INFECTION IN DOGS ATTENDED IN VETERINARY CLINICS FROM PATOS, PARAÍBA STATE, BRAZIL
}

\author{
Annielle Regina Fonseca Fernandes ${ }^{1}$, Sérgio Santos de Azevedo ${ }^{1 *}$, Rosa Maria Piatti ${ }^{2}$, Eliana Scarcelli Pinheiro ${ }^{2}$, \\ Margareth Élide Genovez ${ }^{2}$, Adílio Santos de Azevedo ${ }^{1}$, Carolina de Sousa Américo Batista ${ }^{3}$, Clebert José Alves ${ }^{1}$
}

${ }^{1}$ Laboratório de Doenças Transmissíveis, Unidade Acadêmica de Medicina Veterinária, Centro de Saúde e Tecnologia Rural, Universidade Federal de Campina Grande, Patos, PB, Brasil; ${ }^{2}$ Laboratório de Doenças Bacterianas da Reprodução, Centro de Pesquisa e Desenvolvimento em Sanidade Animal, Instituto Biológico de São Paulo, SP, Brasil; ${ }^{3}$ Departamento de Medicina Veterinária Preventiva e Saúde Animal, Faculdade de Medicina Veterinária e Zootecnia, Universidade de São Paulo, SP, Brasil.

Submitted: April 24, 2010; Approved: June 06, 2011.

\begin{abstract}
To determine the frequency of anti-Brucella canis antibodies in dogs attended in veterinary clinics from Patos, Paraíba State, Brazil, as well as to identify risk factors and to isolate and identify the agent, 193 dogs were used. Agar gel immunodiffusion test (AGID) was used to detect B. canis antibodies in sera. Isolation of B. canis was carried out in blood and bone marrow from seropositive animals. Six animals tested seropositive in AGID, resulting in a frequency of $3.11 \%$. B. canis was isolated from bone marrow of one seropositive animal, with confirmation by PCR. Lack of cleaning of the dog's environment was identified as risk factor (odds ratio $=7.91$ ). This is the first report of isolation of $B$. canis in dogs from the Northeast region of Brazil.
\end{abstract}

Key words: Bacterial diseases, canine brucellosis, prevalence, risk factors, microbiological culture

Canine Brucellosis is an infectious disease of zoonotic potential whose etiologic agent is B. canis, a bacterium responsible for impairment of reproductive tract, primarily abortion and sterility in females and orchitis and epididymitis in males (1). Zoonotic potential of the disease should be taking into account due to complex and close relationship with human population, especially children.

Although clinical signs are usually related to disorders of the reproductive tract, in most cases, even it being a disease of systemic character, the animals are apparently healthy (asymptomatic), behaving as important sources of infection (1).

Etiological diagnosis is performed by detection of antibodies in blood serum or isolation of the agent from infected animals as well as molecular methods $(6,12)$. Bacterial isolation can be done by cultivation of blood and secretions of infected animals and although it provides a definitive diagnosis, this procedure is laborious and timeconsuming and may produce false-negative results.

\footnotetext{
*Corresponding Author. Mailing address: Unidade Acadêmica de Medicina Veterinária, Centro de Saúde e Tecnologia Rural, Universidade Federal de Campina Grande, Patos, Paraíba, Brazil.; E-mail: ssazevedo@cstr.ufcg.edu.br
} 
Serological tests are more practical, quick and easy to implement enabling the execution of a considerable number of samples. However most serological tests are not specific to B. canis and can give false-positive results. Molecular methods such as polymerase chain reaction (PCR) have been widely used for the diagnosis of canine brucellosis enabling the detection of DNA of bacteria in several samples (8).

The aim of this work was to determine the frequency of antiB. canis antibodies in dogs attended in veterinary clinics from Patos, Paraíba State, in the Northeast region of Brazil, as well as to identify risk factors and to confirm the infection by microbiological culture and PCR.

Dogs $\geq 3$ months-old $(\mathrm{n}=193)$ assisted in the Veterinary Medical Center Dr. Leonardo Torres and in the Clinic of Small Animals of the Veterinary Hospital of the Federal University of Campina Grande, Patos, Paraíba, Brazil, from July 2008 to April 2009, were used and selected with the consent of the owners. To identify risk factors, epizootiological questionnaires with closed questions were supplied to each dog owner. These questionnaires were administered by the same interviewer.

Blood (4 mL) was collected without anticoagulant from each dog. Blood samples were centrifuged (2000 X g for $15 \mathrm{~min}$ ) and sera were stored at $-20{ }^{\circ} \mathrm{C}$ prior to testing. From seropositive animals, blood and bone marrow samples were collected. Blood (4 $\mathrm{mL}$ ) was collected from each animal by jugular venal puncture with sodium citrate as anticoagulant. An aliquot $(2 \mathrm{~mL})$ was submitted to bacterial isolation. Bone marrow was collected by iliac crest puncture and $2 \mathrm{~mL}$ were used for bacterial isolation.

Sera were tested by AGID test using Brucella ovis surface antigen, produced in the Instituto Tecnológico do Paraná (Tecpar, Paraná, Brazil). The tests were performed according to the laboratory recommendations, except for the substitution of agarose by $1 \%$ agar Noble (Difco, Detroit, MI, USA).

Risk factors analysis was performed in two steps: univariate and multivariate analysis. Univariate analysis was performed using the Chi-square test or Fisher's exact test (13), and those variables that presented $\mathrm{p} \leq 0.20$ were used for multiple logistic regression. The multivariate analysis was then performed, using the stepwise forward method (5). The significance level in multivariate analysis was $5 \%$. The tests were performed using the SPSS for Windows software package, version 13.0.

For blood and bone marrow cultures $2 \mathrm{~mL}$ of blood with sodium citrate and $2 \mathrm{~mL}$ of bone marrow were inoculated in Castañeda medium and incubated at aerobic atmosphere $\left(37^{\circ} \mathrm{C}\right.$ for 30 days) (1). After growth, colonies were cultured on Brucella agar plates and incubated at aerobic atmosphere at $37^{\circ} \mathrm{C}$ for five days for bacterial identification. Genus characterization was performed using Gram staining and identification of the biochemical profile: catalase, oxidase, citrate, nitrate reduction, motility, $\mathrm{H}_{2} \mathrm{~S}$ production and urease (7).

DNA extraction of isolated bacteria was performed by boiling method $(10,11)$. A $2.3 \times 10^{9}$ bacteria/mL suspended in $1000 \mu \mathrm{L}$ of sterile bi-distilled water, corresponding to 8 on the MacFarland scale, was heated for 10 min to $99{ }^{\circ} \mathrm{C}$, and further used for PCR assay. DNA obtained was stored at $-20{ }^{\circ} \mathrm{C}$ till amplification.

For the reaction primers B4 (5'-TGGCTCGGTTGCCAA TATCAA-3') and B5 (3'-CGCGCTTGCCTTTCAGGTCTG-5') were used to amplify a $223 \mathrm{bp}$ sequence of the gene encoding the periplasmic immunogenic protein BCSP31 specific for Brucella spp. The amplification reaction mixture was prepared in a volume of $50 \mu \mathrm{L}$ containing $200 \mu \mathrm{M}$ of each deoxynucleoside tryphosphate, $50 \mathrm{mM} \mathrm{KCl}, 10 \mathrm{mM}$ Tris- $\mathrm{HCl}$ (pH 9.0), $1.5 \mathrm{mM}$ $\mathrm{MgCl} 2,0.5 \mathrm{mM}$ of each primer, $1.5 \mathrm{U}$ platinum Taq DNA polymerase (Invitrogen, Carlsbad, CA, USA) and $5 \mu \mathrm{L}$ of template DNA. The reaction was performed in a DNA thermal cycler (MJ Research PTC 200 DNA engine, Watertown, MA, USA) without mineral oil. Ultrapure water was used as negative control and Brucella abortus strain ATCC 544 as positive control. After an initial denaturation at $95^{\circ} \mathrm{C}$ for $2 \mathrm{~min}$, the PCR profile was set as follows: $30 \mathrm{~s}$ of template denaturation at $95^{\circ} \mathrm{C}, 30 \mathrm{~s}$ of primer annealing at $62^{\circ} \mathrm{C}$ and $30 \mathrm{~s}$ of primer extension at $72^{\circ} \mathrm{C}$, for a total of 40 cycles, with a final extension at $72^{\circ} \mathrm{C}$ for $5 \mathrm{~min}$. The samples were analyzed by electrophoresis in a $2 \%$ agarose gel and then stained with ethidium bromide $(0.5 \mathrm{mg} / \mathrm{mL})$. The DNA bands were visualized under UV light.

Six animals tested positive at AGID test, resulting in a frequency of $3.11 \%$. In the univariate analysis to determine risk 
factors for $B$. canis infection, variables cleaning of the dog's environment and walking with the dogs were selected (Table 1). Risk factor identified in multivariate analysis by logistic regression was lack of cleaning of the dog's environment (odds ratio $=7.91,95 \% \mathrm{CI}=1.50-41.72, \mathrm{p}=0.015)$, which is plausible from the biological standpoint, since the routine cleaning of the environment with common disinfectants may reduce the survival of bacteria eliminated by infected dogs in the environment, especially in case of parturition or abortion. Therefore, it is suggested that this practice must be commonly adopted in order to avoid exposure of other animals and humans to the risk of infection.

Table 1. Risk factors analysis to Brucella canis seroprevalence in 193 dogs from the Patos municipality, State of Paraíba, in the Northeast region of Brazil.

\begin{tabular}{|c|c|c|c|c|c|c|}
\hline \multirow{2}{*}{ Variables } & \multirow{2}{*}{ Sample size } & \multicolumn{2}{|c|}{ Univariate analysis } & \multicolumn{3}{|c|}{ Multivariate analysis } \\
\hline & & Seropositive (\%) & $\mathbf{p}$ & Odds ratio & IC $95 \%$ & p \\
\hline \multicolumn{7}{|l|}{ Owner education } \\
\hline Illiterate & 2 & $0(0.0)$ & & & & \\
\hline $1^{\text {st }}-8^{\text {th }}$ grade & 82 & $4(4.9)$ & & & & \\
\hline Secondary & 67 & $1(1.5)$ & & & & \\
\hline Higher & 42 & $1(2.4)$ & 0.666 & & & \\
\hline \multicolumn{7}{|l|}{ Sex of the dogs } \\
\hline Female & 83 & $2(2.4)$ & & & & \\
\hline Male & 110 & $4(3.6)$ & 0.701 & & & \\
\hline \multicolumn{7}{|l|}{ Age (months) } \\
\hline $3-6$ & 14 & $0(0.0)$ & & & & \\
\hline $6-12$ & 46 & $2(4.3)$ & & & & \\
\hline $12-24$ & 44 & $2(4.5)$ & & & & \\
\hline$>24$ & 89 & $2(2.2)$ & 0.669 & & & \\
\hline \multicolumn{7}{|l|}{ Breed } \\
\hline Mixed & 110 & $3(2.7)$ & & & & \\
\hline Pure & 83 & $3(3.6)$ & 1.000 & & & \\
\hline \multicolumn{7}{|l|}{ Access to street } \\
\hline No & 140 & $5(3.6)$ & & & & \\
\hline Yes & 53 & $1(1.9)$ & 1.000 & & & \\
\hline \multicolumn{7}{|l|}{ Food } \\
\hline Commercial & 71 & $2(2.8)$ & & & & \\
\hline Prepared at home & 64 & $1(1.6)$ & & & & \\
\hline Scraps & 58 & $3(5.2)$ & 0.510 & & & \\
\hline \multicolumn{7}{|c|}{ Contact with other dogs } \\
\hline No & 93 & $4(4.3)$ & & & & \\
\hline Yes & 100 & $2(2.0)$ & 0.431 & & & \\
\hline \multicolumn{7}{|l|}{ Contact with wildlife } \\
\hline No & 181 & $6(3.3)$ & & & & \\
\hline Yes & 12 & $0(0.0)$ & 1.000 & & & \\
\hline \multicolumn{7}{|l|}{ Dog's environment } \\
\hline Soil & 106 & $4(3.8)$ & & & & \\
\hline Cement & 87 & $2(2.3)$ & 0.692 & & & \\
\hline \multicolumn{7}{|l|}{$\begin{array}{l}\text { Cleaning of the dog's } \\
\text { environment }\end{array}$} \\
\hline Yes & 169 & $3(1.8)$ & & 1 & & \\
\hline No & 24 & $3(12.5)$ & 0.026 & 7.91 & $1.5-41.72$ & 0.015 \\
\hline \multicolumn{7}{|l|}{ Abortion destination } \\
\hline Throw away & 189 & $6(3.2)$ & & & & \\
\hline Burying/burning & 4 & $0(0.0)$ & 1.000 & & & \\
\hline \multicolumn{7}{|l|}{ Walk with the dogs* } \\
\hline No & 72 & $4(5.6)$ & & & & \\
\hline Yes & 121 & $2(1.7)$ & 0.198 & & & \\
\hline \multicolumn{7}{|l|}{ Contact with ponds } \\
\hline No & 164 & $6(3.7)$ & & & & \\
\hline Yes & 29 & $0(0.0)$ & 0,594 & & & \\
\hline
\end{tabular}


Bacteria with morphostaining and biochemical characteristics similar to Brucella spp. was isolated from bone marrow of one seropositive animal. Brucella DNA was extracted from isolated colonies using the boiling procedure and the extracted DNA was amplified using genus-specific primers for Brucella spp.

In this study, the agent was isolated from the bone marrow of one seropositive animal. Although blood is considered the material of choice for the isolation due to long period of bacteremia, $B$. canis can also locate in other lymphoid organs, so that it can be recovered by bone marrow aspirates in the absence of positive blood cultures (6).

The biochemical profile of the isolate was: catalase positive, oxidase positive, citrate negative, nitrate reduction positive, motility negative, $\mathrm{H}_{2} \mathrm{~S}$ production negative and urease positive. The results of biochemical tests are consistent with those obtained in other studies $(3,4,7)$ with the exception of urease positive. Several studies of isolation of $B$. canis found some variations when biochemical tests were performed as Flores Castro et al. (2), which had samples that did not reduce nitrate. Larsson and Costa (9) examined 27 dogs, and 3 had positive blood cultures. When biochemical tests were performed the strains showed production of $\mathrm{H}_{2} \mathrm{~S}$ positive.

The findings described above indicate the presence of $B$. canis infection among pet dogs from Patos, Paraíba State, Brazil, and this work is the first to report the isolation of B. canis in dogs in the Northeast region of Brazil, with confirmation by PCR. Since human infection with B. canis has been reported (12), attention should be paid to possible human infection with this zoonosis through pet dogs and preventive measures must be taken to prevent the transmission. It is suggested that routine cleaning of the dog's environment should be adopted in order to avoid exposure of other animals at risk of infection.

\section{REFERENCES}

1. Carmichael, L. E.; Greene, C. E. (1998). Canine brucellosis. In: Greene,
C.E. (ed). Infectious diseases of the dog and cat. 2. ed. W.B. Saunders, Philadelphia, p.248 257.

2. Flores-Castro, R.; Suarez, F.; Ramirez-Pfeiffer, C.; Carmichael, L. E. (1977). Canine Brucellosis: Bacteriological and Serological Investigation of Naturally Infected Dogs in Mexico City. J. Clin. Microbiol. 6(6): 591597.

3. Godoy, A. M.; Peres, J. N.; Barg, L. (1977). Isolamento de Brucella canis em Minas Gerais, Brasil. Arq. Esc. Vet. Univ. Fed. Minas Gerais 29(1): 35-42.

4. Gomes, M. J. P.; Driemeier, D.; Soares, H. C.; Bastos, C. D.; Canto, S. P.; Brum, M.; Rossi, A. C.; Corbellini, L. G. (1999). Brucella canis: isolamento em um cão com epididimite e orquite - relato de caso. Clínica Veterinária 4(18): 17-20.

5. Hosmer, D.W.; Lemeshow, S. (2000). Applied logistic regression. John Wiley \& Sons, New York, 375p.

6. Johnson, C.A.; Walker, R.D. (1992). Clinical signs and diagnosis of Brucella canis infection. Comp. Contin. Educ. Pract. Vet. 14, 763-772.

7. Keid, L.B.; Soares, R.M.; Morais, Z.M.; Richtzenhain, L.J.; Vasconcellos, S.A. (2004). Brucella spp. isolation from dogs from commercial breeding kennels in São Paulo state, Brazil. Braz. J. Microbiol. 35(1-2): 161-166.

8. Keid, L.B.; Soares, R.M.; Vieira, N.R.; Megid, J.; Salgado, V.R.; Vasconcellos, S.A.; Costa, M.; Richtzenhain, L.J. (2007). Diagnosis of canine brucellosis: comparison between serological and microbiological tests and a PCR based on primers to $16 \mathrm{~S}-23 \mathrm{~S}$ rDNA interspacer. Vet. Res. Commun. 31, 951-965.

9. Larsson, M. H. M. A.; Costa, E. O. (1980). Isolation of Brucella canis. Int. J. Zoonoses 7(2): 125-130.

10. Nishimura, M.; Nukina, M.; Yuan, J.M.; Shen, B.Q.; Jian, J.M.; Ohta, M.; Saida, T.; Uchiyama, T. (1996). PCR-based restriction fragment lengt polymorphism (RFLP) analysis and serotyping of Campylobacter jejuni isolates from diarrheic patients in China and Japan. Fems Microbiol. Let. 142, 133-138.

11. On, S.; Harrington, C.S. (2001). Evaluation of numerical analysis of pfge-dna profiles for differentiating Campylobacter fetus subspecies by comparison with phenotypic, PCR and 16S rDNA sequencing methods. J. Appl. Microbiol. 90, 285-293.

12. Wanke, M.M. (2004). Canine brucellosis. Anim. Reprod. Sci. 83, $195-$ 207.

13. Zar, J.H. (1999). Biostatistical analysis. 4. ed. Prentice Hall, Upper Saddle River, 663p. 